\title{
Odnowa czy od nowa...? Semantyka leksykalna $w$ perspektywie tzw. zwrotu empirycznego* w językoznawstwie XXI wieku
}

„To, co widzimy, zależy od tego, jak patrzymy”.

F. Capra

„To bowiem, co nie ma granic, nie sprawia przyjemności i jest trudne do zrozumienia".

Arystoteles

Słowa klucze: semantyka leksykalna, semantyka strukturalna, zwrot empiryczny w lingwistyce kognitywnej, badania lingwistyczne oparte na korpusie

„Is semanics possible?” pytał H. Putnam w ubiegłym stuleciu (Putnam 1975: 139). Jeśli uznać racje Regut kierowania umystem ${ }^{1}$, w których René Descartes twierdził, iż „Lepiej jest nigdy nie badać, niż zajmować się tak trud-

* Tytuł nawiązuje do wykładu prof. E. Tabakowskiej, «ZZwrot empiryczny» we współczesnym językoznawstwie (kognitywnym)", wygłoszonego 13 marca 2009 r. w Krakowie w ramach Krakowskiej Konferencji Kognitywistycznej „Język odnaleziony”.

1 Tytuł za najnowszym wydaniem traktatu z 2002 r. W wydaniu wcześniejszym z 1958 r. tytuł traktatu został przetłumaczony jako „Prawidła kierowania umysłem”. 
nymi przedmiotami, iż nie mogąc odróżnić prawdy od fałszu, zmuszeni jesteśmy przyjmować to, co wątpliwe, za pewne, albowiem wówczas mniejsza jest nadzieja powiększenia wiedzy niźli niebezpieczeństwo jej zmniejszenia" (Kartezjusz 2002), to dziś, tzn. u schyłku pierwszej dekady XXI wieku, potraktowanie tego pytania w kategoriach rozstrzygnięcia byłoby naiwnością albo aktem desperacji metodologicznej, od których nie są wolne burzliwe konceptualnie losy dociekań semantycznych ${ }^{2}$. Jednakże właśnie dziś, kiedy tzw. discursive turn (Makarov 2003: 13) ) $^{3}$ daniem wielu lingwistów sieje spustoszenie w dotychczasowych aparatach konceptualno-metodologicznych wielu subdyscyplin językoznawczych ${ }^{4}$, prowadząc nawet do prób przedefiniowania samej nauki o języku (Davis, Taylor 1990) z antylingwistyką włącznie (Gethin 1990) ${ }^{5}$, nie zaszkodzi zadać to pytanie ponownie. Choćby w celu rewitalizacji zawartego w nim potencjału deliberatywności z Kartezjańską nadzieją, iż metodyczne powątpiewanie jest środkiem uwalniania umysłu od przesądów i błędów. A że semantyka ze swej natury, którą można by, trawestując tytuł znanej powieści M. Kundery ${ }^{6}$, określić jako „nieznośną lekkość znaczenia", jest - jak twierdzi nie tylko cytowany wyżej H. Putnam - szczególnie na nie podatna (Putnam 1975)7, notabene dzieląc tę tyleż niebezpieczną, co inspirującą skłonność z praktycznie wszystkimi obszarami nauki o języku ${ }^{8}$, nie zaszkodzi ten środek zastosować. Tym bardziej że stan

2 Por.: „Wielu teoretyków języka i poznania skłania się ku poglądowi, iż znaczenia zanalizować się nie da z interesujących teoretycznie powodów" (Wierzbicka 2006: 202). Szerzej na ten temat zob. Szumska 1998, Szumska 2008a.

3 Należy uściślić, iż termin „dyskurs” nie jest tu traktowany jako synonim terminu „tekst”, lecz jako „normy i strategie stojące u podstaw konkretnych wypowiedzi językowych i tekstów" (Labocha 2008: 61). Zob. także Makarov 2003: 87-88.

4 Szerzej na ten temat zob. Szumska 2007.

5 Por. także: „Obecnie dochodzi poniekąd do rozrachunku z lingwistyką, w wyniku którego powstaje konieczność rewizji wcześniejszych kanonów” (Duszak 2002: 34).

6 M. Kundera, Nieznośna lekkość bytu, tłum. A. Holland, Warszawa: PIW 1985 (org. Nesnesitelná lekkost bytì (1984).

7 Por. także: „Nagminne są, jak przekonują dojrzałe próby rewizji lub autorewizji analiz semantycznych, fałsze właśnie w zakresie charakterystyki semantycznej wyrażeń" (Bogusławski 1988: 7-8).

8 Warto sięgnąć tu pamięcią do wielce wymownego passusu z Kursu językoznawstwa ogólnego, traktującego „o pożytku z językoznawstwa”, por.: „(...) w życiu jednostek i społeczeństw mowa jest czynnikiem ważniejszym niż wszystkie inne. [...] w rzeczywistości wszyscy zajmują się nią mniej lub bardziej; a przecież paradoksalna konsekwencja 
badań nad znaczeniem jest fundamentem kondycji poznawczej całego językoznawstwa.

Dobrą, choć gorzką lekcję tej ponadparadygmatycznej prawdy dała pierwsza połowa XX wieku, kiedy to tzw. „peryferyczność” systemu semantycznego ${ }^{9}$ zaczęła w środowisku badaczy języka konotować peryferyczność dociekań semantycznych, a w skrajnych przypadkach, czego przykładem może być deskryptywizm amerykański, wręcz sankcjonować ich umiejscowienie poza granicami lingwistyki.

Ponieważ w rozwoju tej dyscypliny negacja i kontynuacja tworzą symbiotyczną parę, co w języku metodologii nauk określa się jako współistnienie tzw. redukcji hetero- i homogenicznej (Gajda 1990: 33), to dlatego, choć strukturalistyczna restrykcyjność w wytyczaniu granic obszaru badań lingwistycznych ${ }^{10}$ stopniowo ustępuje miejsca, w czym widać działanie prawa redukcji heterogenicznej, antydemarkacyjności kolejnej odsłony nauki o języku $^{11}$, która jak chyba żadna inna (być może ze względu na swój „przedparadygmatyczny” (Tabakowska 2002: 37), a właściwie „międzyparadygmatyczny" charakter) dysponuje nad podziw bogatym repertuarem określeń ${ }^{12}$, powinno się z dużym dystansem podchodzić do opinii, że czasy „ucieczki od znaczenia" bezpowrotnie minęły. I nie chodzi tu bynajmniej o teoretycz-

związanego z nią zainteresowania - nie ma dziedziny, w której zrodziłoby się więcej niedorzecznych poglądów, przesądów, złudzeń i fikcji” (Saussure 2002: 34).

9 W zaproponowanej przez Ch. Hocketta klasyfikacji podsystemów języka ,peryferyczność”, którą cechuje się obok wspomnianego już podsystemu semantycznego także fonetyczny, oznacza powiązanie ze światem pozajęzykowym (Hockett 1968: 159-160).

${ }_{10}$ Mimo iż taką postawę w pełni uzasadniały możliwości metodologiczne szkół strukturalistycznych, była i nadal jest ona poddawana ostrej, bardziej nacechowanej emocjami niż rzeczowej krytyce, por. np.: „Trudno wyobrazić sobie bardziej kastową, masońską naukę, niż lingwistyka. Językoznawcy ciągle się od czegoś odgradzają. Ich ukochanym sposobem pokonywania ideowego przeciwnika jest ogłosić: To nie jest językoznawstwo" (A. E. Kibrik za Issers 2008: 15, tłum. z j. ros. D.S.).

11 Znamienne, że hasłu ,bez granic”, które jak echo pobrzmiewa nie tylko ,jak językoznawstwo długie i szerokie" (jako przykład warto przypomnieć tu żywy odzew, z jakim się spotkała międzynarodowa konferencja „Semantics without Borders”, zorganizowana we wrześniu 2008 r. przez ATH w Bielsku Białej), ale i w wielu dyscyplinach pokrewnych, np. w poetyce (zob. m.in. Bolecki, Tomasik 1995), towarzyszy pytanie o sam kierunek dążenia (zob. m.in. Gajda 1998; Duszak 2002; Brzeziński, Piątkowski 2002), co może świadczyć o tym, że los semantyki jako nauki o nie do końca określonym $\mathrm{i}$ jasnym statusie dzieli wiele gałęzi humanistycznego poznania.

12 Od językoznawstwa „otwartego” przez ,postmodernistyczne”, ,antropologiczne”, „transcendentne” po ,ekologiczne” (Kiklewicz 2006a: 19-20). 
ną możliwość zadziałania mechanizmu redukcji homogenicznej, lecz o fakty przemawiające za tym, że wiek XXI, a przynajmniej jego początek nie tylko nie zwiastuje nadejścia złotego wieku badań semantycznych, ale może potwierdzić celność uwagi A. Wierzbickiej, która nie bacząc na to, że weredycy - jak uczy historia - często i, oczywiście, nie z własnej woli zasilają szeregi heretyków, odważyła się skonstatować, że „w ostatnich dziesięcioleciach semantyka poniosła szkody nie tylko za sprawą swoich wrogów, ale i niektórych przyjaciół" (Wierzbicka 2006: 41). Zdobywając się na odwagę pójścia pod prąd panującym trendom, należy również dodać, że konsekwentne wcielanie w praktykę badawczą pewnych założeń tzw. „nowego myślenia w językoznawstwie" (Tabakowska 2002: 37) ${ }^{13}$, wynikających z dążenia do całkowitego wpisania badań lingwistycznych w kontekst społeczno-kulturowo-antropologiczny ${ }^{14} \mathrm{z}$ towarzyszącym mu zwrotem ku podmiotowości rozważań o języku, może okazać się metodologiczną pułapką dla studiów nad znaczeniem $^{15}$, a więc znów postawić pod znakiem zapytania ich celowość.

Przeorientowanie z tekstu na kontekst interpretacji „zdarzeń komunikacyjnych" ze swoją mocną podbudową teoretyczną w postaci inferencyjnoostensywnego modelu porozumiewania się ${ }^{16}$ istotnie otwiera nowe i obiecujące perspektywy badawcze dla teorii komunikacji i może takie perspektywy otworzyć dla samej lingwistyki, jednakże z pewnym bardzo istotnym zastrze-

13 Jest to także nowe myślenie o samym językoznawstwie jako o nauce interpretatywnej, por.: „Zdecydowanie przeważający w językoznawstwie wzór nauki obiektywnej, empiryczno-teoretycznej, zderza się ze wzorem nauki interpretatywnej" (Gajda 1998: 13), co jest naturalną konsekwencją uznania epistemologii za integralną część teorii naukowej, czyli „odejścia od pewności i poszukiwań prawdy absolutnej jako ostatecznego przedmiotu dociekań naukowych na rzecz a priori ograniczonego i przybliżonego opisu rzeczywistości” (Tabakowska 2002: 41).

14 Jak słusznie zauważa B. Bierwiaczonek, stawia to ,językoznawcę wobec wyboru: albo pozwala, aby jego dyscyplina rozpłynęła się wśród innych nauk o poznaniu i zaczyna dane językowe traktować jako materiał do rozważań i testowania teorii umysłu w ogóle, albo też zachowuje dość niewyraźną autonomię swej dyscypliny, nieustannie jednak posiłkując się wynikami innych nauk o poznaniu i zestawiając własne propozycje teoretyczne z teoriami obowiązującymi w tych naukach" (Bierwiaczonek 2008: 121).

15 I raczej wątpliwą pociechą mogą być w tej kwestii spostrzeżenia S. Gajdy, por.: „Stosunek wielu lingwistów do metodologii bywa dekoracyjny. Jeśli nawet deklaruje się związki z modnym czy "obowiązującym» systemem metodologicznym, dzięki czemu nie wygląda się out of date, to potem pracuje się tak, jak to wydaje się właściwe" (Gajda 1998: 13).

16 Zob. Kerbrat-Orecchioni 1990, 1992, 1994; Kita 1998; Makarov 2003: 33-43. 
żeniem. Otóż „pogoń” nauki o języku za komunikacją ${ }^{17}$, przejawiająca się m.in. we ,włączeniu do językoznawstwa dialektycznej zależności pomiędzy jednostką języka (raczej interpretacją znaczenia jednostki jezzyka, przyp. D.S.) a okolicznościami jej użycia" (Tabakowska 2002: 44) nie może wynikać ze „złudnego ujmowania $\mathrm{z}$ tego samego punktu widzenia języka i mówienia. Globalna całość mowy jest niepoznawalna, ponieważ mowa nie jest jednorodna [...]. Oto jest pierwsze rozdroże, na którym stajemy, z chwilą gdy chcemy stworzyć teorię mowy. Musimy wybrać między tymi dwiema drogami: nie możemy iść obiema naraz, lecz każdą z osobna" (Saussure 2002:47).

Tymczasem entuzjastyczne zastępowanie dwudziestowiecznego systemocentryzmu „kontekstomanią” językoznawstwa początków XXI wieku wręcz prowokuje do popełnienia owego błędu, stwarzając nader sprzyjające warunki, by ulec niezaprzeczalnie silnej, bo tkwiącej, jak zauważa A. Bogusławski, w samym języku, ,pokusie uznania ontycznej rozmytości (wzajemnej) semantyki i pragmatyki” (Bogusławski 2008: 9), a w konsekwencji dążyć do zniesienia granicy pomiędzy dziedziną narzędzi językowych (semantyka) a obszarem działań językowych (pragmatyka). Wybór takiej strategii naukowej ${ }^{18}$, zmierzającej do pogrążenia w intelektualny niebyt wpisanej niejako w charakter semantycznych dociekań drażliwej metodologicznie kwestii docierania do kodowego wymiaru znaczenia jednostek języka, jest pójściem drogą nie tyle rozwiązywania, co unikania rozwiązywania problemów poprzedników ${ }^{19}$, a nawet - jak chcą niektórzy badacze - ,unikania samego języ$\mathrm{ka}^{20}$, na rzecz tworzenia z pozoru nowych, ale w istocie tej samej natury.

17 Tej „pogoni” winna towarzyszyć świadomość, że z samego faktu, iż język jest narzędziem komunikacji, nie wynika, że językoznawstwo jest w stanie wyjaśnić wszystkie jej problemy, zob. m.in. Eco 1996: 123.

18 Taką strategię reprezentuje Langackerowska teoria języka, por.: „Nie widzę apriorycznego powodu, dla którego trzeba by uznać realność dychotomii między semantyką a pragmatyką" (Langacker 2004: 38).

19 By nie powiedzieć intelektualnej bezradności wobec stopnia złożoności tych problemów, por.: „Spojrzenie teoretyczne, pojęciowe, nie musi, a nawet nie może być podporządkowane czemuś zupełnie odmiennemu co do swej natury: trywialnemu stwierdzeniu naszej, ludzkiej, dobrze znanej (a w przypadku zjawisk językowych, przyznać trzeba, szczególnie dotkliwej) nieporadności, niewydolności czy nieudolności w postępowaniu praktycznym, w stosowaniu pojęć do materiału, w wytyczaniu granic" (Bogusławski 2008: 8).

${ }^{20}$ Por.: „Ogólny obraz zmian w językoznawstwie teoretycznym określić można jako stopniowe «unikanie języka». [...] paradygmat transcendentny uwzględnia przede wszystkim znaki symptomatyczne" (Kiklewicz 2007: 43). 
Trudno bowiem nie zauważyć, że nawet, jeśli definicja semantyczna staje się (sic!) kryptopragmatyczna, bo tak wypada zakwalifikować efekt wprowadzenia w czyn koncepcji „ukontekstowienia znaczenia” ${ }^{21}$, notabene podważającej zasadę „optymalizacji dawkowania werbalnych i niewerbalnych nośników informacji w komunikacji językowej” (Kiklewicz 2006b: 143), to i tak bez podania kryteriów określania zakresu kluczowego w tej definicji kontekstowego odniesienia ${ }^{22}$, oznacza powrót do dyskusji na temat granic procedury eksplikacyjnej struktury pojęciowej jednostek leksykalnych. Ponadto dając, a w najlepszym razie podpowiadając, przyzwolenie na bezpośrednie przekładanie charakterystyki tekstowej znaku na jego charakterystykę systemową ${ }^{23}$, skutkujące przypisywaniem jednostkom leksykalnym nieograniczonej pojemności semantycznej, a co za tym idzie kierujące analizę znaczeniową wprost w pułapkę wieloznaczności ${ }^{24}$, urealnia niebezpieczeństwo dążenia tej analizy do regresu nieskończonego ${ }^{25}$. Zwłaszcza gdy strategia ta znajduje iluzoryczne potwierdzenie w zjawisku tzw. dyfuzji semantycznej, które można by nazwać swoistym „komunikacyjnym rozluźnieniem semantycznych obyczajów"26, odbieranym jako „zmierzch werbocentryzmu” (Wysłouch 1995: 40). Obserwowana w wyniku tego zjawiska, i co ważne uwiarygodniona za sprawą dostępu do danych korpusowych, coraz większa

21 Por.: „Znaczenie jest kontekstem” (Tabakowska 2002: 37).

22 Por.: „Odniesienie do kontekstu przywołuje wciąż powracający problem zakresu” (Tabakowska 2002: 44).

23 Trudne do zaakceptowania nie tylko ze strukturalistycznego punktu widzenia, por.: „Znaczenie tekstowe wyrazu niezmiernie rzadko pokrywa się z wartością wynikającą z budowy systemu. Na płaszczyźnie tekstu dochodzą dwa nowe czynniki precyzujące treść, a mianowicie [...] kontekst i konsytuacja” (Milewski 2005: 59).

24 Jako skrajny przykład efektów takiego podejścia mogą posłużyć wymykające się wszelkim próbom syntezy i trudne do udźwignięcia przez słowniki opisy znaczenia leksykalnego zarówno przymiotników odrzeczownikowych typu morski, jak i adiektywów wartościujących typu dobry. Szerzej na ten temat zob. Szumska 2006: 94-104.

25 Tak samo jak wpisywanie do znaczenia słowa wiedzy o jego denotacie, czyli ,encyklopedyczne spojrzenie na semantykę językową" (Langacker 2004: 38). Zob. także tzw. „błąd mędrców z Lagado” (Szumska 2008b: 26).

${ }^{26}$ Wydaje się dyskusyjne, a przynajmniej przedwczesne, sytuowanie tego zjawiska również w samym systemie języka, jak czyni to A. Kiklewicz, por.: „Dyfuzję semantyczną definiujemy jako niedookreślenie czy też niezdeterminowanie treści znaków różnego formatu [...], rozmyty charakter granic między znaczeniami i kategoriami znaczeniowymi w semantycznym systemie języka oraz w komunikacji językowej” (Kiklewicz 2006c: 12). 
różnorodność kontekstów, w jakich może pojawić się dana jednostka leksykalna, jest pretekstem do destrukcyjnej atomizacji analiz znaczeniowych. Nawet jeśli jest to naturalna, a więc w pełni zrozumiała reakcja na wręcz ascetyczny redukcjonizm semantyki składnikowej, nie może ona być podszyta „lękiem przed uogólnieniami”, który nie tyle wiedzie do „idiograficznego raju" 27 , co - tak samo jak swego czasu „lęk przed znaczeniem” - skutecznie hamuje rozwój semantyki, która „ma być maksymalnie restrykcyjna, minimalistyczna. Wyraża się to w szczególności w postulacie maksymalnego ubóstwa ładunku poznawczego przypisywanego wyrażeniom [...], a więc w postulacie minimalizacji przyjmowanej «wieloznaczności» wyrażeń” (Bogusławski 2008: 25) ${ }^{28}$. Przyjęcie tego postulatu wiąże się z podjęciem trudnego wyzwania znalezienia jedności w wielości, a więc przełożenia bogactwa własności kombinatorycznych jednostek leksykalnych na owo „maksymalne ubóstwo ładunku poznawczego", czy też stopień systemowego niedookreślenia znaczenia ${ }^{29}$, który determinuje zakres kooperacji struktury pojęciowej tych jednostek z kontekstem językowym i pozajęzykowym.

Obranie drogi przeciwnej w połączeniu z tzw. „zwrotem empirycznym” w językoznawstwie, polegającym m.in. na przedkładaniu ,świata danych” nad „dane ze świata”, a więc oznaczającym zwrot w kierunku badań korpusowych $^{30}$, grozi nie tylko utonięciem refleksji teoretycznej w morzu jednostkowych faktów, ale także uśpieniem metodologicznej czujności badaczy poprzez wykreowanie iluzorycznej wizji statystyki (która jak stereotypy nie jest ani prawdziwa, ani fałszywa, ale wygodna) jako skutecznego antidotum

27 Por.: „Raj lingwistów, w którym czas upływa im na idiograficznych badaniach poszczególnych użyć [...] jest [...] mrzonką" (Gellner 1984: 455). Warto również przypomnieć w tym miejscu rozterki S. Ullmana, który przestrzegał przed niewdzięcznością i nieefektywnością zadania, sprowadzającego się do ,zbierania i analizowania kontekstów, w których występuje dany wyraz" (Ullman 1991: 340).

28 Por. także: „Samo istnienie intuicyjnej wiedzy o języku przyjmuję a priori jako aksjomat. Natomiast jej pełna, eksplicytna reprezentacja za pomocą adekwatnego narzędzia językoznawczego nie jest i zapewne nigdy nie będzie możliwa" (Grochowski 2008: 34).

29 Rozumianego jako obecność w strukturze semantycznej danej jednostki zmiennych pojęciowych, zob. Szumska 2006: 94.

30 Rozróżnienie na „dane ze świata” (the data of the world) i ,świat danych” (the world of the data) i per analogiam na badania ilustrowane korpusem (corpus-illustrated) i badania oparte na korpusie (corpus-based) zob. Geeraerts 2006. Informacje pochodzą ze wspomnianego już wykładu prof. E. Tabakowskiej (Kraków 2009). 
zdolnego przegonić widmo introspekcji, krążące nad analizami znaczeniowymi, a stąd już tylko krok do ich ograniczenia do ekscerpcji korpusowej. Stąd w kwestii korpusów zdecydowanie należy podzielić stanowisko J. Linde-Usiekniewicz, która słusznie podkreśla, iż choć ,,analiza zaświadczeń korpusowych pozwala badaczowi ustrzec się przedwczesnych i nadmiernych generalizacji” (Linde-Usiekniewicz 2008: 167), to ,analizy semantyczne nie moga jednak ograniczyć się do ekscerpcji korpusowej" (Linde-Usiekniewicz 2008: 168). A zatem badacz i tak jest prędzej, czy później skazany na samotność wśród semów, bo tylko na nim, a nie na danych statystycznych spoczywa ciężar uzasadnienia przyjętych rozstrzygnięć definicyjnych, zwłaszcza że w naukach interpretatywnych, a do takich obecnie zalicza się bądź chce być zaliczane językoznawstwo, metody ilościowe muszą ustąpić pierwszeństwa jakościowym.

Ponadto należy pamiętać, na co również zwraca uwagę w cytowanym wyżej artykule Linde-Usiekniewicz (2008: 167), że choć korpus jest bezkonkurencyjnie najobfitszym źródłem materiału językowego, to jednak nie w pełni wyczerpującym. Innymi słowy, fakt braku zaświadczenia korpusowego dla danej jednostki, czy też konstrukcji nie może być dla badacza dowodem jej niewystępowania na poziomie komunikacyjnym. Po drugie, poza granicami korpusów pozostają konstrukcje okazjonalne, często łamiące w swej warstwie powierzchniowej prawa kombinatoryki sensów ${ }^{31}$, niezwykle cenne dla semantyka jako dostarczające empirycznego impulsu do konstruowania tzw. ,lingwistycznego eksperymentu” (Sannikov 2008: 34-35), znanego także jako metoda gwiazdkowa (Szumska 2006: 35).

Jeśli zatem tzw. propagowany przez lingwistykę kognitywną „,Zwrot empiryczny" ma rzeczywiście być wielkim zwrotem, a nie cichym powrotem do przeszłości w badaniach semantycznych, nie może zaprzepaścić w imię zapomnianej, niestety, w nauce o języku zasady kumulatywizmu, ich dotychczasowych strukturalnych ${ }^{32}$ dokonań metodologicznych, tym bardziej że - jak pisze A. Bogusławski - „od ostatniego słowa o walorze operacyjnym, którego wielu badaczy wygląda, dzieli nas wciąż bardzo znaczny dystans" (Bogusławski 2008: 89). Tym bardziej zatem warto zadawać sobie i innym

31 Por. np. piękna katastrofa [Tele Tydzień 2006:46], urocza katastrofa [Tele Tydzień 2008: 43].

32 Wszak semantyka strukturalna, tak jak i sam strukturalizm, miała i nadal ma niejedno imię (Linde-Usiekniewicz 2008). 
badaczom zacytowane na początku tych rozważań pytanie, pamiętając przy tym, że wytyczanie granic nie oznacza ograniczania horyzontów poznawczych, tylko może uczynić trudne możliwym do zrozumienia. Dlatego bezkrytyczne wcielanie w życie idei „semantyki bez granic”, którą propaguje „,nowe myślenie” w językoznawstwie XXI wieku, choć skutkujące pożądanym wzrostem zainteresowania tą dyscypliną, może paradoksalnie pozbawić ją tożsamości, a więc i przyszłości ${ }^{33}$.

\section{Bibliografia}

Bierwiaczonek B., 2008, Czy językoznawstwo kognitywne jest autonomiczne?, w: P. Stalmaszczyk (red.), Metodologie językoznawstwa. Wspótczesne tendencje i kontrowersje, Kraków: Lexis, s. 120-131.

Bierwisch M., 1986, Semantyka składnikowa, tłum. z j. ang. A. Weinsberg, Przeglad Humanistyczny 11/12, s. 109-121.

BogusŁawski A., 1988, Język w słowniku: desiderata semantyczne do wielkiego słownika polszczyzny, Studia Leksykograficzne 2, Wrocław: Ossolineum.

BogusŁawski A., 2008, Semantyka, pragmatyka. Leksykografa głos demarkacyjny, Warszawa: Wydawnictwo Takt.

Bolecki W., Tomasik W. (red.), 1995, Poetyka bez granic, Warszawa: IBL.

BRZEZiŃski J., PiąTKowski C., 2002, Teoretyczno-metodologiczne podstawy badań językoznawczych nad stylem tekstów artystycznych, w: Z. Krążyńska, Z. Zagórski (red.), Poznańskie Spotkania Językoznawcze, t. IX, Poznań: Wydawnictwo Poznańskiego Towarzystwa Przyjaciół Nauk, s. 19-28.

Davis H. G., Taylor T. S. (red.), 1990, Redefining Linguistics, London: Routledge.

Duszak A., 2002, Dokąd zmierza tzw. lingwistyka tekstu?, w: Z. Krążyńska, Z. Zagórski (red.), Poznańskie Spotkania Językoznawcze, t. IX, Poznań: Wydawnictwo Poznańskiego Towarzystwa Przyjaciół Nauk, s. 29-37.

Eco U., 1996, Nieobecna struktura, tłum. A. Weinsberg, P. Bravo, Warszawa: Wydawnictwo: KR.

Gajda S., 1990, Wprowadzenie do teorii terminu, Opole: Wyższa Szkoła Pedagogiczna im. Powstańców Śląskich w Opolu.

33 „Although the structuralist era of linguistics was over-zealous in its «discovery» of arbitrariness, let us not make the same mistake by searching too long for ubiquitous motivation" (Glynn 2005: 285). 
GajDA S., 1998, Językoznawstwo na rozdrożu?, w: E. Jędrzejko (red.), Nowe czasy, nowe języki, nowe (i stare) problemy, Katowice: Wydawnictwo Uniwersytetu Śląskiego, s. 11-19.

Geeraerts D., 2006, Methodology in Cognitive Linguistics, w: G. Kristiansen, M. Achard, R. Dirven i F. J. Ruiz de Mendoza Ibáňez (red.), Cognitive Linguistics: Current Applications and Future Perspectives, Berlin-New York: Mouton de Gryuter, s. 21-50.

GelLner E., 1984, Stowa i rzeczy, czyli nie pozbawiona analizy krytyka filozofii lingwistycznej, Warszawa: Książka i Wiedza.

Gethin A., 1990, Antilinguistics: A Critical Assesment of Modern Linguistic Theory and Practise, Oxford: Intellect Books.

GLYNn D., 2005, Iconicity and the grammar-lexis interface, w: E. Tabakowska, Ch. Ljungberg, O. Fischer (red.), Insistent Images, Amsterdam-Philadelphia: John Benjamins Publishing Company, s. 269-288.

Grochowski M., 2008, Rola dewiacji w uzasadnianiu hipotez semantycznych. Wprowadzenie do problematyki, Biuletyn Polskiego Towarzystwa Językoznawczego $L X I V$, s. 25-36.

Hockeтt Ch., 1968, Kurs językoznawstwa współczesnego, tłum. z j. ang. Z. Topolińska, M. Jurkowski, Warszawa: PWN.

Issers O. S., 2008, Kommunikativnye strategii i taktiki russkoj reczi, Moskva: Izdatel'stvo LKI.

Kartezjusz, 2002, Reguly kierowania umystem. Poszukiwanie prawdy przez światto naturalne, tłum. L. Chmaj, Kęty: Antyk.

Kerbrat-Orecchioni C., 1990, Les interactiones verbales, t. I, Paris: Armand Colin.

Kerbrat-Orecchioni C., 1992, Les interactiones verbales, t. II, Paris: Armand Colin.

Kerbrat-Orecchioni C., 1994, Les interactiones verbales, t. III, Paris: Armand Colin.

Kiklewicz A., 2006a, Język. Komunikacja. Wiedza, Mińsk: BTAA „Prawa i ekanomika”.

Kiklewicz A., 2006b, Forma, Biuletyn Polskiego Towarzystwa Językoznawczego LXII, s. 129-145.

KiKLewicz A., 2006c, Dyfuzja semantyczna w języku i tekście I, LingVaria 1, s. 11-21.

KiKLewicz A., 2007, Aspekty teorii względności lingwistycznej, Olsztyn: Instytut Dziennikarstwa i Komunikacji Społecznej UWM w Olsztynie.

Kita M., 1998, Przemiany modelu komunikacji werbalnej, w: E. Jędrzejko (red.), Nowe czasy, nowe języki, nowe (i stare) problemy, Katowice: Wydawnictwo Uniwersytetu Śląskiego, s. 71-85.

Laвосна J., 2008, Tekst, wypowiedź, dyskurs w procesie komunikacji językowej, Kraków: Wydawnictwo Uniwersytetu Jagiellońskiego. 
LANGACKer R., 1995, Wykłady z gramatyki kognitywnej, H. Kardela (red.), Lublin: Wydawnictwo Uniwersytetu Marii Skłodowskiej-Curie.

LANGACKer R., 2004, Semantyka językoznawcza, Etnolingwistyka 16, s. 29-73.

Linde-Usiekniewicz J., 2008, Semantyka strukturalna w XXI wieku, w: P. Stalmaszczyk (red.), Metodologie językoznawstwa. Współczesne tendencje i kontrowersje, Kraków: Lexis, s. 158-173.

Makarov M., 2003, Osnovy teorii diskursa, Moskva: Gnozis.

Milewski T., 2005, Językoznawstwo, Warszawa: Wydawnictwo Naukowe PWN.

Putnam H., 1975, Is Semantics Possible?, w: Mind, Language and Reality. Philosophical Papers, Cambridge: Cambridge University Press, s. 139-152.

SANNIKov V. Z., 2008, Russkij sintaksis v semantiko-pragmaticzeskom prostranstvie, Moskwa: Jazyki slavjanskich kul'tur.

SAUSSURE DE F., 2002, Kurs językoznawstwa ogólnego, tłum. K. Kasprzyk, Warszawa: Wydawnictwo Naukowe PWN.

Szumska D., 1998, Znaczenie: enfant terrible semantyki i leksykografii, Biuletyn Polskiego Towarzystwa Językoznawczego LIV, s. 45-61.

Szumska D., 2006, Przymiotnik jako przyłaczone wyrażenie predykatywne. Analiza formalizacji struktur propozycjonalnych $w$ warunkach predykacji niezdaniotwórczej, Kraków: Universitas.

Szumska D., 2007, Dekada dekadencji? Frustracje lingwisty(ki) XXI wieku, Polonica XXVIII, s. 5-11.

Szumska D., 2008a, Od ignorancji do relewancji: tropem nierozwiązanych problemów semantyki leksykalnej, Biuletyn Polskiego Towarzystwa Językoznawczego LXIV, s. 37-47.

SzUMSKA D., 2008b, In vocabulario veritas? Słowo o słowniku (ogólnym), w: W. Szczukin (red.), Pamięć serca. Liber amicorum. Tom jubileuszowy dedykowany Danucie Piwowarskiej, Kraków: Wydawnictwo Uniwersytetu Jagiellońskiego, s. 21-29.

TABAKOwsKa E., 2002, Nowe myślenie paradygmatyczne w językoznawstwie: znaczenie jest kontekstem, w: J. Odżyński, T. Rittel (red.), Konteksty kulturowe w dyskursie edukacyjnym, Kraków: Oficyna Wydawnicza „Edukacja”, s. 37-47.

Ullmann S., 1991, Pojęcie znaczenia, tłum. J. Bralczyk, w: J. Pelc, L. Koj (red.), Semiotyka dziś i wczoraj, Wrocław: Ossolineum, s. 334-341.

WierzBiCKA A., 2006, Semantyka leksykalna. Jednostki elementarne i uniwersalne, tłum. z j. ang. A. Głaz, Lublin: Wydawnictwo Uniwersytetu Marii Curie-Skłodowskiej.

WysŁouch S., 1995, Werbocentryzm - uzurpacje i ograniczenia, w: W. Bolecki, W. Tomasik (red.), Poetyka bez granic, Warszawa: IBL, s. 32-40. 
The beginning or from the beginning? Lexical semantics in the context of the so-called „empirical turn” in the 21st century linguistics

( su m mary)

The paper explores the issue of the development of semantics under the circumstances of ,the new linguistic thinking”, which promotes the idea of semantics without borders, and the so-called „empirical-turn” in linguistic investigation. The uncritical fascination with corpus-data, which could be considered as a natural reaction against the promotion of subject-oriented nature of meaning, leads to the substitution of the quest for meaning for the statistical data. On the other hand, the idea of „no borders" endangers the autonomy of semantics as a science. 